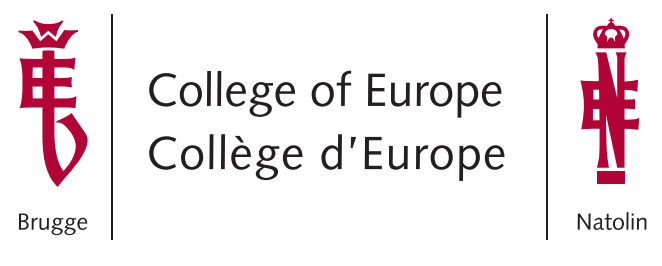

\title{
Interconnecting Legal Systems and the Autonomous EU Legal Order: A Balloon Dynamic Inge Govaere
}

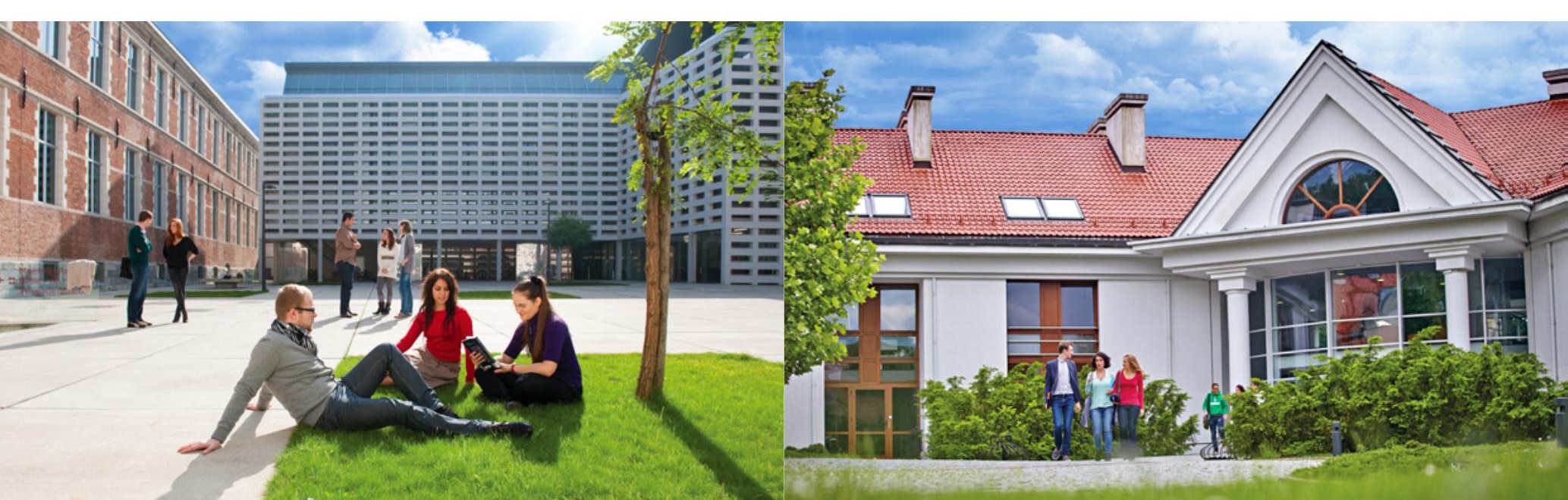

DEPARTMENT OF

EUROPEAN LEGAL STUDIES

Research Paper in Law

$02 / 2018$ 


\section{RESEARCH PAPERS IN LAW}

$2 / 2018$

Inge Govaere

Interconnecting Legal Systems and the Autonomous EU Legal Order:

A Balloon Dynamic 


\title{
Interconnecting Legal Systems and the Autonomous EU Legal Order: A Balloon Dynamic*
}

\author{
Inge Govaere**
}

\section{The Balloon Dynamic of the Autonomous EU Legal Order}

The concept of the new and autonomous EU legal order, as it emanated from the historic Van Gend \& Loos judgment of the Court of Justice of the European Union (CJEU), ${ }_{1}^{1}$ can best be pictured as an empty balloon firmly slid in-between public international law and constitutional law. ${ }^{2}$ At first this would sit somewhat uneasily and create some friction, but it would not yet raise any major concerns. More important frictions with international law however started to appear with the rapid expansion of the EU integration process both in terms of substantive coverage and territorial scope, due to the constant transfer of competence towards the EU, coupled with the EU enlargement process to include new Member States. The balloon imagery goes that with every such new EU development, more air is automatically blown into the balloon. Yet strongly inflating the EU balloon has as a direct consequence that also more and more international law (and Member States' constitutional law) is systematically squeezed out. It is this gradual but steady EU integration process which inevitably causes increased friction and possibly even resistance against a further expansion of the autonomous EU legal order. Not surprisingly, the biggest friction is likely to relate to the transfer of areas which for a long time were kept outside the EU law balloon and within the sole realm of international law.

Concurrently, the EU legal order, as any balloon, gets more fragile when inflated. The necessity to shield the balloon from 'external puncturing' and its ensuing deflation, for instance in terms of forum shopping for dispute settlement, therefore also becomes all the stronger. It was argued before that this gradual EU integration process most likely explains why the crucial debate on EU law compatibility of ISDS in the new and comprehensive EU free trade agreements, such as TTIP, CETA and EUSFTA, has only recently arisen. ${ }^{3}$ The underlying trigger is undoubtedly the express inclusion of foreign direct investments in Article 207 of the Treaty on the Functioning of the European Union (TFEU) by the Lisbon Treaty, thus unequivocally conferring exclusive common commercial policy competence in the matter to the EU. ${ }^{4}$ In so doing, a field traditionally governed by international law was for the first time brought firmly within the balloon of the autonomous EU legal order. In the much awaited Opinion 1/17, the questions posed by Belgium pertain to the compatibility of the ISDS provisions in

\footnotetext{
* The final version will be published in the book: I Govaere and S Garben (eds), The Interface between EU and International Law: Contemporary Reflections, Hart Publishing, 2018 (forthcoming).

${ }^{* *}$ Inge Govaere is Jean Monnet Chair in EU Legal Studies and Director of the Ghent European law Institute (G.E.L.I.) at Ghent University and Director of the European Legal Studies Department, College of Europe, Bruges.

${ }^{1}$ Case 32/84 Van Gend \& Loos ECLI:EU:C:1985:104.

2 This 'balloon dynamic' was first presented at the 2016 FIDE congress in Budapest, see I Govaere, 'TTIP and Dispute Settlement: Potential Consequences for the Autonomous EU Legal Order' in G Bándi, P Barak, K Debisso (eds), Speeches and Presentations from the XXVII FIDE Congress, Congress Proceedings Vol 4, 2016, 123-44.

${ }^{3}$ For opposing views, see for instance E-U Petersmann, 'Transformative Transatlantic Free Trade Agreements without Rights and Remedies of Citizens?' (2015) Journal of International Economic Law 579-607; R Quick, 'Why TTIP Should Have an Investment Chapter Including ISDS' (2015) Journal of World Trade 199-209.

4 I Govaere, 'TTIP and Dispute Settlement: Potential Consequences for the Autonomous EU Legal Order' (2016) 1 College of Europe Research Papers in Law 5-6.
} 
CETA with the autonomous EU legal order post-Lisbon. ${ }^{5}$ Advisory Opinion 1/00 on the European Common Aviation Area shows, however, that it does not suffice to raise questions in terms of possible incompatibility with the EU autonomous legal order for the CJEU also to conclude in that sense ${ }^{6}$ the assessment is much more refined and complex.

Such a complex balloon dynamic process warrants the following threefold analysis. First of all, it is crucial to remember the very raison d'être of the EU law balloon and the mechanisms underlying its inflation, so as to understand why and how the CJEU coined the concept of 'autonomous EU legal order' in Van Gend \& Loos. $^{7}$ Many studies and conferences have already been devoted to the study of Van Gend \& Loos so this will not be repeated here. ${ }^{8}$ Second, in order to avoid puncturing the balloon membrane it is crucial to pinpoint clearly the structural pressures that rest on the autonomous EU legal order. Third, it needs to be considered what the possible degree of resilience or elasticity of the EU balloon membrane can be in terms of offering substantive remedies to avoid conflict. The latter two elements are necessarily and inherently intertwined in any single legal analysis performed by the CJEU. The structural membrane serves to safeguard the 'autonomy' of the EU legal order so that, not surprisingly, the CJEU will strive for a strict division and a 'hermetically closed' EU law system. Yet in order to forge acceptance thereof, the CJEU needs, at the same time, to be seen to strive for 'openness' and 'symbioses' with the other legal systems in terms of substantive resilience/elasticity, in relation to both constitutional law of the Member States and international law (including the UN, European Convention for the Protection of Human Rights and Fundamental Freedoms (ECHR)). This contribution will systematically deconstruct those last two distinct yet stringently interrelated elements before turning to the key question in the current Post-Lisbon setting: will the EU balloon likely continue to fly or deflate?

The Lisbon Treaty now expressly states among the EU objectives in Article $3(5)$ of the Treaty on European Union (TEU) that the Union '... shall contribute to (...) the development of international law, including respect for the principles of the United Nations Charter'. Upon an isolated reading of this new provision of primary EU law, it could be claimed that this objective should always and necessarily take the upper hand and in every instance be given a full effect. The question still remains if, and if so to what extent, in so-doing concessions can or should be made to safeguard the autonomy of the EU legal order, which also derives its logic from primary EU law. Another possibility is more simply to read a codification of consistent case law of the CJEU into this new provision. As an international actor with legal personality the EU should then in its dealings with third countries and other international organisations comply with and contribute to the international legal order, short of any obligation to turn the EU into a traditional 'state like' subject of international law, let alone yielding core features of EU law to international law. There is no doubt that the insertion of

5 The questions addressed by Belgium to the CJEU are the following: 'Specifically, the Kingdom of Belgium is requesting the CJEU to provide an opinion regarding the compatibility of the ICS with:

1) The exclusive competence of the CJEU to provide the definitive interpretation of European Union law

2) The general principle of equality and the "practical effect" requirement of European Union law

3) The right of access to the courts

4) The right to an independent and impartial judiciary'

see 'CETA: Belgian Request for an Opinion from the European Court of Justice' at https://diplomatie.belgium.be/en/newsroom/news/2017/minister_reynders_submits_request_opinion_cet a (last accessed 11 September 2018).

${ }^{6}$ Opinion 1/00 ECAA ECLI:EU:C:2002:231. The CJEU came to the conclusion that 'The system of legal supervision proposed by the Agreement on the establishment of a European Common Aviation Area in Articles 17, 23 and 27 and Protocol IV is compatible with the EC Treaty'.

7 Van Gend \& Loos (n 1).

${ }^{8}$ See, amongst others, CJEU, '50th Anniversary of the Judgment in Van Gend en Loos' 19632013, Conference proceedings, Luxembourg, 13 May 2013, EU publications. 
this provision in the Lisbon Treaty contains ample potential to refuel a difficult discussion.

In order to grasp the complexity, dynamics and current challenges facing this interconnecting process, it is crucial that the place of the autonomous EU legal order in the larger international legal setting is subjected to a dynamic reassessment on its own merits and, importantly, free from hindsight reasoning. The focus lies on a onesided analysis, exclusively from an EU law perspective. Equally crucial and interesting questions emerging from a complementary international law perspective, such as determining the impact of EU law on international law and the 'accommodation' of the EU by other international organisations, will thus be left aside. By way of additional caveat, as the focus is exclusively put on an EU legal analysis, mainly trying to understand the logic of the CJEU, political and economic issues of interconnecting legal orders will only be considered as contextually important but not form the focus of analysis as such.

\section{Structural Pressure on the Balloon Membrane}

A lot of attention has traditionally gone on the study of the (intra-balloon) development of EU law, looking at the specificities and subject matters of EU law. ${ }^{9}$ This concerns the essential and distinctive characteristics of EU law, namely primacy, direct effect and uniform interpretation by the CJEU, ${ }^{10}$ but also transfer of competence to the EU in various and ever increasing fields. ${ }^{11}$ The balloon dynamic of interaction between EU law and international law is not, however, limited to the process of inflation of the balloon with its ongoing shift in competence towards the EU. It also, if not foremost, points to the need to maintain intact a balloon membrane surrounding that ever expanding autonomous EU legal order. Seen from this perspective, the role of the CJEU in safeguarding a hermetically closed system of EU law appears to be crucial for the very survival of the authenticity of the autonomous EU legal order. The common feature to be discerned in the CJEU's approach is that it seeks to prevent any 'direct' interference of international law within the EU balloon, unless it has been expressly endorsed as 'integrated' or 'incorporated' into the EU legal order. ${ }^{12}$ The challenges here are twofold for the EU legal order as set up by Van Gend \& Loos and continue to be subject to both internal and external structural pressures, and also following the Lisbon Treaty. First, the CJEU's approach to the structural internal pressure post-Lisbon will be briefly pinpointed and some (wider) lessons drawn, before turning to the highly topical issue of increasing external structure pressure.

\section{A. Structural Internal Pressure and the Rule of 'EU' Law}

From within, the structural pressure on the hermetically closed EU law system essentially comes from the intergovernmental elements surviving the abolishment of the pillar structure by the Lisbon Treaty in CFSP matters. The crux of the autonomous EU legal order consists in preserving the unique position bestowed upon the CJEU by the Treaties. Articles 19 TEU and 344 TFEU combined confer exclusive jurisdiction to the CJEU, thereby as a rule preventing forum shopping and

${ }^{9}$ See, eg, A Rosas, L Armati, EU Constitutional Law, an Introduction (Hart Publishing, 2018); R Schütze, European Union Law (Cambridge University Press, 2015).

${ }_{10}$ See, eg, KJ Alter, Establishing the Supremacy of European Law: The Making of an International Rule of Law in Europe (Oxford University Press, 2010); S Weatherill, Law and Values in the European Union (Oxford University Press, 2016).

${ }_{11}$ On this issue, see S Garben and I Govaere (eds), The Division of Competences between the European Union and its Member States: Reflections on the Past, Present and Future (Hart Publishing, 2017).

12 See below. 
excluding any form of international dispute settlement in relation to the intra-balloon issues of EU law. An important exception thereto is still to be found in the "horizontal pillar' of CFSP, ${ }^{13}$ in principle excluding CJEU jurisdiction for CFSP matters other than Article $40 \mathrm{TEU}^{14}$ and restrictive measures against natural or legal persons (Articles 24(1) TEU ${ }^{15}$ and 275 TFEU $\left.^{16}\right)$. As such, whereas the political power to act is shifted from the Member States to the EU, the judicial control mechanism continues to remain outside the EU legal order. ${ }^{17}$ Judicial control over CFSP measures thus lies primarily with the domestic courts of the Member States as well as international courts, such as the European Court of Human Rights (ECtHR). ${ }^{18}$

According to the Treaties, the CFSP is thus sort of half in and half out of the EU law balloon. It is to a large extent kept outside judicial control by the CJEU in favour of political control mainly by the Council and the High Representative. ${ }^{19}$ Nonetheless, the CJEU uses its general jurisdiction to ensure the rule of law under Article 19 TEU in order to minimise the possible negative impact thereof on the autonomous EU legal system. It does so in two ways, one in relation to CFSP agreements, the other relating to autonomous CFSP decisions.

13 See I Govaere, 'Multi-faceted Single Legal Personality and a Hidden Horizontal Pillar: EU External Relations Post-Lisbon' (2010-2011) 13 Cambridge Yearbook of European Legal Studies 87112.

${ }^{14}$ Art 40 TEU: 'The implementation of the common foreign and security policy shall not affect the application of the procedures and the extent of the powers of the institutions laid down by the Treaties for the exercise of the Union competences referred to in Articles 3 to 6 of the Treaty on the Functioning of the European Union.

Similarly, the implementation of the policies listed in those Articles shall not affect the application of the procedures and the extent of the powers of the institutions laid down by the Treaties for the exercise of the Union competences under this Chapter.'

${ }^{15}$ Art 24(1) TEU stipulates: 'The Union's competence in matters of common foreign and security policy shall cover all areas of foreign policy and all questions relating to the Union's security, including the progressive framing of a common defence policy that might lead to a common defence.

The common foreign and security policy is subject to specific rules and procedures. It shall be defined and implemented by the European Council and the Council acting unanimously, except where the Treaties provide otherwise. The adoption of legislative acts shall be excluded. The common foreign and security policy shall be put into effect by the High Representative of the Union for Foreign Affairs and Security Policy and by Member States, in accordance with the Treaties. The specific role of the European Parliament and of the Commission in this area is defined by the Treaties. The Court of Justice of the European Union shall not have jurisdiction with respect to these provisions, with the exception of its jurisdiction to monitor compliance with Article 40 of this Treaty and to review the legality of certain decisions as provided for by the second paragraph of Article 275 of the Treaty on the Functioning of the European Union.'

${ }^{16}$ Art 275 TFEU reads as follows: 'The Court of Justice of the European Union shall not have jurisdiction with respect to the provisions relating to the common foreign and security policy nor with respect to acts adopted on the basis of those provisions.

However, the Court shall have jurisdiction to monitor compliance with Article 40 of the Treaty on European Union and to rule on proceedings, brought in accordance with the conditions laid down in the fourth paragraph of Article 263 of this Treaty, reviewing the legality of decisions providing for restrictive measures against natural or legal persons adopted by the Council on the basis of Chapter 2 of Title $\mathrm{V}$ of the Treaty on European Union.'

17 I have labelled this elsewhere as 'crippled' conferral, see I Govaere, 'To Give or to Grab: The Principle of Full, Crippled and Split Conferral of Powers Post-Lisbon' in M Cremona (ed), Structural Principles in EU External Relations Law (Hart Publishing, 2018) 71-91.

${ }^{18} \mathrm{See}, \mathrm{eg}, \mathrm{ECtHR}, \mathrm{MSS} v$ Belgium and Greece, Application No 30696/09, Judgment of 21 January 2011, at para 338: 'The Court notes the reference to the Bosphorus judgment (...). The Court found that the protection of fundamental rights afforded by Community law was equivalent to that provided by the Convention system (ibid, $\S 165$ ). In reaching that conclusion it attached great importance to the role and powers of the Court of Justice of the European Union (CJEC) - now the CJEU - in the matter, considering in practice that the effectiveness of the substantive guarantees of fundamental rights depended on the mechanisms of control set in place to ensure their observance (ibid, $\S 160$ ). The Court also took care to limit the scope of the Bosphorus judgment to Community law in the strict sense - at the time the "first pillar" of European Union law (§ 72).'

${ }^{19}$ Art 24(3) TEU. 
First of all, the CJEU deftly uses the unitary procedure for the conclusion of agreements as laid down in Article 218 TFEU, 'an autonomous and general provision of constitutional scope', ${ }^{20}$ to try to ensure some coherence in terms of the level of judicial and democratic control within the broader EU law balloon. ${ }^{21}$ The CJEU thus refutes the arguments of the Council to the effect that it would totally lack jurisdiction as soon as it concerns a CFSP agreement. Instead, it points out that an exception to the rule of general jurisdiction conferred upon the CJEU by Article 19 TEU should necessarily be restrictively interpreted..$^{22}$

In the same vein, the CJEU in the Rosneft case ${ }^{23}$ firmly claimed jurisdiction to give preliminary rulings on the validity of unilateral decisions adopted in relation to the CFSP prescribing restrictive measures against natural or legal persons, in spite of the express Treaty reference only to Article 263 TFEU procedures in that respect. The reasoning employed is as follows:

Since the purpose of the procedure that enables the Court to give preliminary rulings is to ensure that in the interpretation and application of the Treaties the law is observed, in accordance with the duty assigned to the Court under Article 19(1) TEU, it would be contrary to the objectives of that provision and to the principle of effective judicial protection to adopt a strict interpretation of the jurisdiction conferred on the Court by the second paragraph of Article 275 TFEU, to which reference is made by Article 24(1) TEU. ${ }^{24}$

Two distinct lessons can be drawn from those cases, one specific to CFSP and one more generally applicable to the specificity of EU law as compared to international law.

First, although those two remedies fall short of giving the CJEU full jurisdiction with respect to CFSP, they go a long way towards including CFSP matters in the autonomous EU legal order balloon, thereby somewhat alleviating the structural internal pressure. The exact extent of the CJEU's CFSP interpretation exercise is not yet fully in view. ${ }^{25}$ But, as the CJEU may not engage in contra legem interpretation of express Treaty provisions, certain CFSP matters are bound to remain outside the EU balloon at least until a further Treaty amendment. This then implies that for those aspects of CFSP, legal control if any will continue to be effected at the sole national and international level, including by the ECtHR. ${ }^{26}$ The importance of the CJEU judicial review of Article 40 TEU in terms of qualifying the external action of the EU as CFSP-based or not therefore also remains high post-Lisbon.

Second and perhaps more importantly, the more general lesson to be drawn is that the reasoning employed in both cases relies heavily on the role attributed by

\footnotetext{
${ }^{20}$ Case C- 425/13 Commission v Council (Negotiating directives) ECLI:EU:C:2015:483, para 62.

21 See Case C- 658/11 EP v Commission (Mauritius Agreement) ECLI:EU:C:2016:435; Case C- 263/14 EP v Council (Tanzania Agreement) ECLI:EU:C:2016:435.

22 Mauritius Agreement, ibid, at para 70: 'Nevertheless, the final sentence of the second subparagraph of Article 24(1) TEU and the first paragraph of Article 275 TFEU introduce a derogation from the rule of the general jurisdiction which Article 19 TEU confers on the Court to ensure that in the interpretation and application of the Treaties the law is observed, and they must, therefore, be interpreted narrowly.'

${ }^{23}$ Case C- 72/15 Rosneft ECLI:EU:C:2017:236. For an analysis, see S Poli, 'The Common Foreign Security Policy after Rosneft: Still Imperfect but Gradually Subject to the Rule of Law' (2017) Common Market Law Review 1799-1834.

${ }^{24}$ Rosneft, ibid, at para 75.

${ }^{25}$ See, eg, C Hillion, R Wessel, 'The Good, the Bad and the Ugly: Three Levels of Judicial Control over the CFSP' in S Blockmans and P Koutrakos (eds), Research Handbook on EU Common Foreign and Security Policy (Edward Elgar Publishing, forthcoming 2018); R Wessel, 'Integration and Constitutionalisation in EU Foreign and Security Policy' in R Schülze (ed), Governance and Globalization (Cambridge University Press, at press); G Butler, 'The Coming of Age of the Court's Jurisdiction in the Common Foreign and Security Policy' (2017) European Constitutional Law Review 673-703.

${ }^{26}$ See also ECtHR, MSS v Belgium and Greece (n 18).
} 
Article 19 TEU to the CJEU to safeguard and to enforce respect for the rule of specifically 'EU' law. The CJEU made it amply clear already in Advisory Opinion 2/13 on the accession of the EU to the ECHR that it is not sufficient for the EU, under CFSP, to comply with the rule of law under control of the ECHR, in particular if at the same time compliance with the rule of 'EU' law through the CJEU was not guaranteed. ${ }^{27}$ The Rosneft case further imposes a combined reading under Article 19 TEU of the duty of the CJEU to ensure full respect of EU law with the CJEU's earlier finding, in Les Verts, ${ }^{28}$ that the EU Treaties set up a 'complete' and coherent system of effective judicial remedies in which also the national judges fulfil a crucial role through the preliminary reference procedure. ${ }^{29}$ As both Opinion $1 / 09^{30}$ and the recent Achmea ${ }^{31}$ case seem to confirm, any attempt to withdraw jurisdiction from the national courts in relation to areas covered by intra-EU balloon matters is therefore also likely to fall foul of the EU autonomous legal order. ${ }^{32}$

\section{B. Structural External Pressure}

The latter finding illustrates that it is mainly the external structural pressure coming from more traditional international law settings that forces the CJEU to define what precisely constitutes the autonomy of the EU legal order which may not be affected by international law. The criticism towards cases such as the Kadi33 saga, Opinion $2 / 13,{ }^{34}$ as well as the discussions triggered by Achmea, ${ }^{35}$ has exposed the

27 Opinion 2/13 EU Accession to ECHR ECLI:EU:C:2014:2454 para 254-57: '254. Nevertheless, on the basis of accession as provided for by the agreement envisaged, the ECtHR would be empowered to rule on the compatibility with the ECHR of certain acts, actions or omissions performed in the context of the CFSP, and notably of those whose legality the Court of Justice cannot, for want of jurisdiction, review in the light of fundamental rights.

255. Such a situation would effectively entrust the judicial review of those acts, actions or omissions on the part of the EU exclusively to a non-EU body, albeit that any such review would be limited to compliance with the rights guaranteed by the ECHR.

256. The Court has already had occasion to find that jurisdiction to carry out a judicial review of acts, actions or omissions on the part of the EU, including in the light of fundamental rights, cannot be conferred exclusively on an international court which is outside the institutional and judicial framework of the EU (see, to that effect, Opinion 1/09, EU:C:2011:123, paragraphs 78, 80 and 89).

257. Therefore, although that is a consequence of the way in which the Court's powers are structured at present, the fact remains that the agreement envisaged fails to have regard to the specific characteristics of EU law with regard to the judicial review of acts, actions or omissions on the part of the EU in CFSP matters.'

${ }^{28}$ Case 294/83 Les Verts v European Parliament EU:C:1986:166

${ }^{29}$ Rosneft (n 23) at para 76: 'In those circumstances, provided that the Court has, under Article 24(1) TEU and the second paragraph of Article 275 TFEU, jurisdiction ex ratione materiae to rule on the validity of European Union acts, that is, in particular, where such acts relate to restrictive measures against natural or legal persons, it would be inconsistent with the system of effective judicial protection established by the Treaties to interpret the latter provision as excluding the possibility that the courts and tribunals of Member States may refer questions to the Court on the validity of Council decisions prescribing the adoption of such measures.'

30 Opinion 1/09 European and Community Patents Court ECLI:EU:C:2011:123.

${ }^{31}$ Case C-284/16 Achmea ECLI:EU:C:2018:158.

32 Unless the alternative dispute settlement method introduced may be fully equated with a domestic court of the Member States for the sake of Art 267 TFEU procedures, including as regards forging compliance with the duty to refer.

${ }_{33}$ For the appeal judgments of the CJEU, see Joined Cases C-402/05 P and C-415/05 P Kadi I ECLI:EU:C:2008:461; Joined Cases C- 584/10 P, C- 593/10 P and C- 595/10 P Kadi II ECLI:EU:C:2013:518. The Kadi saga quickly triggered much doctrine, see, eg, the overview given in $S$ Poli, M Tzanou, 'The Kadi Rulings: A Survey of the Literature' (2009) Yearbook of European Law 53358; A Cuyvers, "'Give Me One Good Reason”: The Unified Standard of Review for Sanctions after Kadi II' (2014) Common Market Law Review 1759-88; C Gearty, 'In Praise of Awkwardness: Kadi in the CJEU' (2014) European Constitutional Law Review 15-27.

34 See, eg, P Eeckhout, 'Opinion 2/13 on EU Accession to the ECHR and Judicial Dialogue: Autonomy or Autarky' (2015) Fordham International Law Journal 995; E Spaventa, 'A Very Fearful 
conceptual difficulty of maintaining a closed EU law balloon which is hermetically shielded from international law. The crucial question appears to be whether one can or should be able to identify situations whereby the possibility of forum shopping between the application of EU law or international law is at all warranted. Should UN law and obligations be singled out as such a special case, in particular in view of the above mentioned reference thereto in Article 3(5) TEU? What about the ECHR as expressly mentioned in Article 6 TEU? Or should, in keeping with the zest of the Lisbon Treaty, the question perhaps be answered positively as soon as other subjects of international law, in particular states, would be willing to engage in such a forum shopping exercise regardless of the subject matter? The reasoning then goes that the maturing of the EU into a forceful international actor as envisaged by the Lisbon Treaty necessarily implies that, within its competence, it may assume all rights and obligations as if it were a state. The key question is, of course, whether in a post-Lisbon setting the EU may really simply be equated with a state, or whether it still has distinct characteristics and special features that need to be reckoned with.

The Lisbon Treaty continues to give a strong argument to the CJEU to counter any such general 'state-like' acceptance of international forum shopping; such an interpretation would be difficult to square with, and potentially even undermine, the exclusive jurisdiction of the CJEU under the above mentioned Article 344 TFEU and Article 19 TEU combined. ${ }^{36}$ This express exclusion of international dispute settlement by the Treaties applies in a horizontal manner to all matters brought within the EU law balloon. The distinction to be made then is not so much in relation to the importance, or not, of the international legal setting invoked or whether or not states would engage in certain international practices. It is to the contrary solely determined by the nature of the parties and the disputes in which international law is invoked. As such, the CJEU has acknowledged that dispute settlement mechanisms included in international agreements may be turned to in order to settle disputes between, on the one hand, the EU and/or its Member States and, on the other hand, third countries. ${ }^{37}$ Triggering external dispute settlement in such cases is not only indicated but necessary as the CJEU, being the domestic supreme court of the EU, has no international jurisdiction over such disputes. At the same time, the CJEU has unequivocally stated in the $M_{0}{ }^{38}$ case that to invoke such external dispute settlement mechanisms in order to solve disputes between Member States, and most likely also between the EU and its Member States, for matters falling within EU competence conflicts with the exclusive jurisdiction conferred on the CJEU by Article 344 TFEU combined with Article 4 TEU, the duty of sincere cooperation. The CJEU clarified that considering the hierarchy of norms, dispute settlement provisions in international agreements even if introducing a specialised forum can never set aside those express Treaty obligations. ${ }^{39}$

Yet this alone is not sufficient to hermetically close the EU law balloon. Additionally, the CJEU has indicated that at least the following conditions need to be

Court? The Protection of Fundamental Rights in the European Union after Opinion 2/13' (2015) Maastricht Journal of European and Comparative Law 35-56.

${ }^{35}$ Achmea (n 31), see the various blog posts which quickly picked up on this judgment, awaiting more thorough scholarly analysis.

${ }^{36}$ Distinct from other international courts set up by agreements, such as the International Court of Justice or the ECtHR.

37 Opinion 1/76 Draft Agreement establishing a European laying-up fund for inland waterway vessels ECLI:EU:C:1977:63 at para 5. This is the case for most international agreements.

${ }^{38}$ C-459/03 Commission v Ireland (Mox) ECLI:EU:C:2006:345.

39 For an analysis, see I Govaere, 'Beware of the Trojan Horse: Dispute Settlement in (Mixed) Agreements and the Autonomy of the EU Legal Order' in C Hillion and P Koutrakos (eds), Mixed Agreements Revisited: The EU and its Member States in the World (Hart Publishing, 2010) 187-207. 
met to safeguard the autonomy of the EU legal order. ${ }^{40}$ First of all, the interpretation of provisions of an international agreement pursuant to external dispute settlement should not be binding on the EU as concerns the interpretation and application of internal EU law. ${ }^{41}$ Second, the agreement may not lead to an undermining of the objectives enshrined in Article 19 TEU, which apparently should increasingly be understood as respect for the 'rule of EU law' considered as a whole. ${ }^{42}$ More than just guaranteeing the CJEU's exclusive jurisdiction for reviewing the legality of EU, this then also means safeguarding the CJEU's crucial role in ensuring the uniform interpretation of EU law as well as safeguarding the position of Member States' courts. ${ }^{43}$ Third, the essential character of the powers of the EU and its institutions 'as conceived in the Treaty should remain unaltered'. ${ }^{44}$ This implies that external dispute settlement should not affect the allocation of powers between the EU and the Member States, but also that the function of the different EU institutions remain unaffected, in particular also that the CJEU is by its very nature a court whose decisions are binding. These conditions have been progressively clarified in case law but are not necessarily exhaustive. As new questions emerge, for instance in relation to the potential effect of ISDS on the autonomy of the EU legal order, ${ }^{45}$ it is to be expected that new and more refined answers may also be formulated by the CJEU in the future whenever it considers it necessary to shield the internal application and development of EU law from the effect of external and international forms of dispute settlement. One can easily understand why for the CJEU it is crucial that the specific and autonomous EU balloon is to be shielded from puncturing by international law interference, however small, as such would inevitably entail the risk of a more or less rapid deflation.

With the coming into force of the Lisbon Treaty, the question nonetheless emerges more forcefully whether the horizontal scope of the exclusive jurisdiction of the CJEU could and should continue to apply without any exception at all. As mentioned above, the newly stated objectives of the EU now include contributing 'to the development of international law, including respect for the principles of the United Nations Charter' (Article 3(5) TEU). ${ }^{46}$ Does compliance with this objective of necessity require a limitation on the scope of application of the rule of EU law? A positive answer would imply that such an objective was not already successfully pursued by the EU before the Lisbon Treaty. Although at times there may have been friction, there seem to be no compelling examples of (lasting) conflict between EU and UN law to support such a view. As will be argued below, this objective in most cases can continue to be met by the CJEU, within the framework of its exclusive jurisdiction, provided that sufficient attention is given to the resilience or elasticity of the EU law balloon in order to avoid situations of open conflict with international law in general and UN legal obligations in particular. ${ }^{47}$

It is, however, more difficult to easily reach the same conclusion with respect to the express statement in Article 6(2) TEU that '(t)he Union shall accede to the European Convention for the Protection of Human Rights and Fundamental Freedoms'. ${ }^{48}$ This new provision inserted by the Lisbon Treaty necessarily and unequivocally prescribes adherence to the jurisdiction of the ECHR. Only the terms

40 See also I Govaere, 'TTIP and Dispute Settlement: Potential Consequences for the Autonomous EU Legal Order' (2016) 1 College of Europe, Research Papers in Law 6.

41 Opinion 1/91 EEA / ECLI:EU:C:1991:490.

${ }^{42}$ See above.

43 Opinion 1/09 European Patent Court (n 30).

${ }^{44}$ Opinion 1/00 ECAA (n 6).

${ }^{45}$ See Opinion 1/17 ISDS Provision in CETA (pending) (n 5).

46 See above.

47 See below. Treaties'.

48 It continues: 'Such accession shall not affect the Union's competences as defined in the 
of such accession conditions are left to be negotiated in conformity with the EU Treaties. A crucial and novel issue thereby is to what extent, if any, Article 6 TEU necessarily limits, or provides an exception to, the horizontal scope of the exclusive jurisdiction of the CJEU for all matters of EU law within the EU balloon. In Advisory Opinion $2 / 13,{ }^{49}$ the CJEU does not really address this fundamental question. Instead, it performs a straightforward and systematic check of the draft accession agreement in terms of its compatibility with the autonomous EU legal order. The reference frame thus seems to be that the EU legal order and the exclusive jurisdiction of the CJEU need to be fully safeguarded at all costs, similarly to the standard approach also adopted in relation to any other international agreement concluded by the EU. Not surprisingly, therefore, the outcome of this assessment was negative and the draft accession agreement was found to be incompatible with the Treaties.

Opinion 2/13 thereby leaves wide open the thorny question of the post-Lisbon interpretation to be given to the core Treaty provisions at stake. Does Article 6(2) TEU have equal force and hierarchical ranking to Articles 19 TEU and 344 TFEU? If so, how do those provisions interrelate? In particular, how could each provision be given an 'effet utile', possibly even a renewed interpretation, considering that they are on the same footing as norms of primary EU law? It seems that if Opinion 2/13 may be subject to criticism, then it is not so much for the CJEU's repeated and forceful attempts to hermetically keep the EU balloon closed. It is rather for doing so without coming to terms with the legal complexities introduced by the Lisbon Treaty and a lack of reflection about the necessity and possible ways in which to redesign the balloon.

\section{Necessary Resilience/Elasticity of the Balloon}

The hermetically closed balloon of EU law can, however, only withstand the structural pressure from international law and be shielded from puncturing if EU law proves sufficiently resilient to accommodate international law concerns. This implies that in its case law the CJEU, as guardian of the autonomous EU legal order, shows sufficient flexibility in addressing issues of international law so as to avoid creating situations of open conflict. In other words, it is submitted that the capacity for the EU to maintain an enduring structural autonomy necessarily goes hand in hand with continuously and proactively fostering a relationship of symbiosis rather than clash with international law. Different from a state, the autonomy of the EU legal order is only conditionally accepted so long as there is no open conflict in substance with fundamental values of constitutional and international law. It is important to note that such appraisal ultimately rests not only with the CJEU. It is subject to scrutiny by external fora, in particular the Member States' constitutional courts ${ }^{50}$ and the $\mathrm{ECtHR},{ }^{51}$ leading to a kind of 'silent constitutional dialogue'.

The CJEU case law seems to meet such concerns in two distinct ways. The first option for the CJEU is to 'incorporate' or 'integrate' international law elements into the formulation of EU law, so as to render the requirements under both legal systems compatible. The second subsidiary option is to conclude to an incompatibility between EU law and international law obligations but at the same time to provide a pragmatic intermediary solution so as to avoid an immediate clash

\footnotetext{
49 Opinion 2/13 (n 27).

50 See, eg, JA Frowein, 'Solange II, (BVerfGE 73, 339) Constitutional Complaint Firma W' (1988) Common Market Law Review 201-06; I Canor, 'My Brother's Keeper? Horizontal Solange: "An Ever Closer Distrust among the Peoples of Europe' (2013) Common Market Law Review 383-421.

51 See, eg, C Costello, 'The Bosphorus Ruling of the European Court of Human Rights: Fundamental Rights and Blurred Boundaries in Europe' (2006) Human Rights Law Review 87-130; G Harpaz, 'The European Court of Justice and its Relations with the European Court of Human Rights: The Quest for Enhanced Reliance, Coherence and Legitimacy' (2009) Common Market Law Review 105-41.
} 
between the two legal orders at stake. Up until now this two-pronged approach has proved on the whole sufficient to avoid open and long lasting conflicts between legal orders, but it cannot be excluded that in the future a different reflection and possible Treaty changes may be warranted.

For the sake of completion, attention will also briefly be drawn to a last option which is expressly written into the Treaties for the benefit of the sole Member States, not the EU as such. It concerns the possibility to set aside conflicting EU Treaty obligations in favour of complying with prior Treaty obligations or for reasons of security interest. These Treaty provisions may facilitate the finding that a Member State is in breach of its EU law obligations as it allows the balloon to be gently pushed aside without any risk of puncturing.

\section{A. Finding of Compatibility between Legal Orders}

In most cases the CJEU endeavours to develop a reasoning in pursuit of a finding of compatibility between EU and international law. The delicate exercise consists in firmly asserting the specificity of EU law against the backdrop of international law obligations of both the EU and its Member States. As the friction between EU law and international law increases and solutions become more difficult to find, the CJEU however seems to be less inclined to accommodate arguments relating to the sole position of the Member States, at least if this would render the finding of a compatibility with EU law more precarious. ${ }^{52}$

A major difficulty resides in the fact that the reference frame to conclude to a compatibility, or not, between the two legal orders is necessarily international law. This implies that it is primarily the CJEU that has to incorporate elements of international law into EU law, and to do so to a sufficient extent, rather than vice versa. ${ }^{53}$ But the CJEU is only a domestic court of the EU and not an international court, so it is not in a position to render an authoritative 'international' interpretation of international law. Its interpretations of international law are only for domestic use, merely binding on the EU and its Member States within the context of EU law applications. It is important, therefore, that the CJEU is as much as possible 'seen' to defer appreciations of international law to international treaties and in particular as interpreted by the competent international courts, such as the ECtHR and ICJ. Where no such firmly established external benchmark is at hand, the CJEU is most vulnerable to exposing itself to critique of having wrongfully asserted jurisdiction and misinterpreted international law. ${ }^{54}$

The express references already made by the CJEU early on to the ECHR and to the case law of the ECHR, at a time when the EU Treaties were silent in this respect, are clear and early examples of this preferred solution. Such references to a foreign legal order and to rulings of a foreign court, in the absence of membership of the EU to the ECHR, illustrate the understanding of the CJEU that the new and autonomous EU legal order cannot function in complete and splendid legal isolation. Instead, symbiotic and complementary systems of law had to be set up. It is interesting to point out that a similar approach seemed to be shared by the ECtHR in its famous Bosphorus judgment. ${ }^{55}$ After scrutiny of the case law of the CJEU in terms of judicial

\footnotetext{
52 See below.

${ }^{53}$ Although a certain extent of mutual influence may be noted, for instance when the ECHR refers CJEU case law.

54 Such as in relation to the rather blunt assertion of the CJEU in the Racke case that the procedural provisions in the Vienna Convention on the Law of Treaties is not part of customary international law, Case C-162/96 Racke ECLI:EU:C:1998:293 at para 59. For a case comment, see J Klabbers, 'Case C-162/96, A Racke GmbH \& Co v Hauptzollamt Mainz judgment of 16 June 1998, nyr' (1999) Common Market Law Review 179-89.

${ }^{55}$ ECtHR Bosphorus Hava Yollari Turizm ve Ticaret Anonim Siketi v Ireland 2005-VI 42 EHRR 1 (Bosphorus). See inter alia T Lock, 'Beyond Bosphorus; The European Court of Human Rights' Case
} 
protection and protection of fundamental rights, the ECHR introduced a legal presumption of 'equivalent protection' in the EU which can only be rebutted in case of manifest deficiencies. ${ }^{56}$ The ECHR is also seen to refer to case law of the CJEU to support its own legal arguments. ${ }^{57}$

More recent examples concern the deference to customary international law principles and case law of the ICJ, first tentatively in the Racke ${ }^{58}$ case and more openly since the $A T A A^{59}$ case. This follows earlier case law where the CJEU already stated that the EU is necessarily bound to respect international law and not just the agreements which the EU itself has concluded. ${ }^{60}$ As a consequence, in its legality control of secondary acts of the EU the CJEU will no longer hesitate to take into consideration the need for the EU to respect principles of customary international law, even if those are codified in agreements to which the EU is not a party. ${ }^{61}$ This is however to be distinguished from compatibility with international agreements in two respects.

First, it may be more difficult to determine what precisely constitutes a principle of customary international law. As the ATAA case illustrates, the CJEU will defer to express rulings of the ICJ where they are at hand. ${ }^{62}$ It will also be rather precautious in assessing whether there are any divergent views among the Member States and the EU institutions as to the existence of a generally accepted qualification as principle of customary international law. ${ }^{63}$

Second, and somewhat related to the first point, the CJEU has pointed out that since a principle of customary international law does not have the same degree of precision as a provision of an international agreement, judicial review must necessarily be limited to the question whether, in adopting the act in question, the institutions of the European Union made manifest errors of assessment concerning the conditions for applying those principles. ${ }^{64}$

On the other hand, even though the nature of judicial review enacted by the CJEU will thus necessarily be limited to a marginal judicial review, the CJEU has accepted that principles of customary international law may also be invoked by individuals to contest the validity of secondary EU law. ${ }^{65}$ This leads to a rather paradoxical finding that under certain circumstances respect for international law

Law on the Responsibility of Member States of International Organisations under the European Convention on Human Rights' (2010) Human Rights Law Review 529-45; P Gragl, 'An Olive Branch from Strasbourg? Interpreting the European Court of Human Rights' Resurrection of Bosphorus and Reaction to Opinion 2/13 in the Avotinsš Case: ECtHR 23 May 2016, Case No 17502/07, Avotiņš v Latvia' (2017) European Constitutional Law Review 551-67.

56 Yet rebuttable in case of manifest deficiencies.

57 On the interaction between the two courts before and after Opinion 2/13, see F Fabbrini, J Larik, 'The Past, Present and Future of the Relation between the European Court of Justice and the European Court of Human Rights' (2016) Yearbook of European Law 145-79.

58 Racke (n 54).

${ }^{59}$ Case C-366/10 Air Transport Association of America (ATAA) ECLI:EU:C:2011:864.

61 See Joined Cases 21/72 to 24/72 International Fruit Company ECLI:EU:C:1972:115.

61 Such as the Chicago Convention in the ATAA case, or the Vienna Convention on the Law of Treaties in the Racke case.

${ }^{62}$ ATAA (n 59) at para 104

${ }^{63}$ ATAA (n 59) at para 105-106. In casu the CJEU found that three out of the four principles were not contested and withheld as principles of customary international law. However the fact that both Germany and the UK had disputed that the $4^{\circ}$ principle, namely that aircraft overflying the high seas are subject to the exclusive jurisdiction of the State in which they are registered, led the CJEU to conclude there was 'insufficient evidence' to establish this as a principle of customary international law.

${ }^{64}$ ATAA (n 59) at para 110.

65 This is subject to two conditions: 'first, those principles are capable of calling into question the competence of the European Union to adopt that act', (..), 'and, second, the act in question is liable to affect rights which the individual derives from European Union law or to create obligations under European Union law in his regard'. See ATAA (n 59) at para 107. 
principles may be better enforceable through the 'prism' of the EU law balloon than in the international legal order as such.

\section{B. Finding of Incompatibility between Legal Orders}

Considering that EU law is not fully tantamount to international law, there remain of course a number of situations whereby the outcome under an EU law analysis and an international legal analysis may be different and even conflicting. It is therefore unavoidable that the CJEU might in a specific case come to a finding of EU law which is incompatible with concurrent international law obligations of the EU or the Member States. This type of case which cannot be 'absorbed' through the resilience of the autonomous EU legal order presents the highest risk of puncturing the EU law balloon.

More often than not, the CJEU seems to anticipate a frontal clash between those legal orders by providing a pragmatic intermediary solution. Where needed it may allow for the conflicting EU law obligations to be temporarily put aside in favour of meeting international obligations in the short term. The condition appears to be, however, that in the middle to long term the incompatibility is resolved in favour of meeting the specific EU law obligations. Usually such a remedy is to be effected at the sole EU and/or Member State level but, exceptionally and if need be, it may also be found at the international level with the acquiescence of the third states concerned.

Such situations will often arise when the EU has contracted international obligations on a wrong legal basis, so that in principle the agreement is null and void under EU law but perfectly valid and enforceable under international law, whereas there is no real dispute as to its content. It may then suffice to temporarily stay the effects of the judgment so as not to disrupt the EU international relations whilst allowing for the adoption of the decision concluding the agreement using the correct legal basis. The CJEU thereby often expressly points to the need to avoid creating serious disruptions or negative consequences for the Union's relationship to third countries which might arise in case the contested decision would be annulled without its effects being maintained. ${ }^{66}$ Especially in a post-Lisbon context of multiple competence-related litigation, this remedy seems to have become almost a standard practice, often granted on demand of and with agreement of all or most of the parties involved. ${ }^{67}$ Yet, as the rationale is to allow for some time to adopt the necessary measures in order to smoothly remove the indicated incompatibility in favour of compliance with EU law, the remedy may need to be tailor-made to the international context of each case whilst avoiding unwarranted and continuing disruptions to the application of EU law. The main variations therefore relate to the duration of the remedy offered, ranging from a mandatory fixed number of months, ${ }^{68}$ to a more open-ended phrasing such as 'the effects of that decision should be maintained until it is replaced'. ${ }^{69}$ In other cases a somewhat in-between position is taken, whereby the CJEU maintains 'the effects of the contested decision until the entry into force, within

66 See, eg, Case C- 660/13 Council v Commission (Access by the Swiss Confederation to the internal market) ECLI:EU:C:2016:616 at para 53: 'If the contested decision were annulled without its effects being maintained, that may give rise to serious negative consequences for the Union's relationship with the Swiss Confederation'.

67 See, eg, C- 658/11 EP v Council (Mauritius Agreement) ECLI:EU:C:2014:2025 at para 88: 'Both the Parliament and the Council, and the majority of the intervening Member States, request that, should the Court annul the contested decision, the effects of that decision be maintained until it is replaced'.

68 See, eg, Case C- 137/12 Commission v Council (conditional access) ECLI:EU:C:2013:675 at para 81: 'In the interests of legal certainty, therefore, it is appropriate for the Court to maintain the effects of that decision until the adoption, within a reasonable period which must not exceed six months, of a new decision based on the appropriate legal bases, namely Article 207(4) TFEU, together with Article 218(5) TFEU'.

69 See, eg, Case C- 263/14 EP v Council (Tanzania Agreement) ECLI:EU:C:2016:435 at para 86. 
a reasonable period of time, of a new decision to replace it' ${ }^{70}$ thus leaving the appreciation of the duration needed to comply with EU law open-ended but not limitless.

The more problematic cases are those where such a judge-made short term remedy to avoid a clash between EU and international obligations is to no avail. Typically this would concern disputes relating to content rather than competence, which require a renegotiation of the EU position and/or the international commitments. Any solution to divert an open conflict between EU and international law obligations would then necessarily need to be approved also by the third countries involved, without there being any obligation and perhaps little incentive for the latter to do so. This is where the importance of the Advisory Opinion procedure of Article 218(11) TFEU takes its full weight. ${ }^{71}$ As the CJEU has pointed out, the very purpose of this procedure is

to forestall complications which would result from legal disputes concerning the compatibility with the Treaty of international agreements binding upon the Community. In fact, a possible decision of the Court to the effect that such an agreement is, either by reason of its content or of the procedure adopted for its conclusion, incompatible with the provisions of the Treaty could not fail to provoke, not only in a Community context but also in that of international relations, serious difficulties and might give rise to adverse consequences for all interested parties, including third countries. ${ }^{72}$

Stated differently, the aim of this procedure is to prevent the EU from incurring international liability for engaging into international commitments with which it will not be able to comply for breach of EU law. ${ }^{73}$ The existence of this preventive procedure is however no guarantee that such conflicts may at all times be avoided. Article 218(11) TFEU needs first of all to be triggered by one of the EU institutions or a Member State and even so there is no standstill obligation awaiting the outcome. Political considerations may take the upper hand regardless of the potential legal consequences. The troubled legal path of the EU-USA Passenger Name Records (PNR) Agreement is a prime example in this respect, having started with an Advisory Opinion procedure to proceed to an annulment case and finally the adoption of a new agreement based on the former third pillar outside the control of the CJEU ${ }^{74}$ In the

70 See, eg, Council v Commission (Access by the Swiss Confederation to the internal market) (n 66) at para 54.

${ }^{71}$ For an analysis of this procedure, see S Adam, La Procédure d'avis devant la Cour de Justice de I'Union européenne (Bruylant, 2011).

72 Opinion 1/75 (Export credits) ECLI:EU:C:1975:145 at pt A. The CJEU continues to explain: 'for the purpose of avoiding such complications the Treaty had recourse to the exceptional procedure of a prior reference to the Court of Justice for the purpose of elucidating, before the conclusion of the agreement, whether the latter is compatible with the Treaty. this procedure must therefore be open for all questions capable of submission for judicial consideration, either by the Court of Justice or possible by national courts, in so far as such questions give rise to doubt either as to the substantive or formal validity of the agreement with regard to the Treaty'.

${ }^{73}$ I have argued elsewhere that the Advisory Opinion procedure is in needed of thorough revision and reflection, see I Govaere, 'Setting the International Scene: EU External Competence and Procedures Post-Lisbon Revisited in the Light of ECJ Opinion 1/13' (2015) Common Market Law Review 1277-1308.

74 In particular the European Parliament (EP) and the Council were opposed in this respect as concerns the first PNR Agreement with the USA. First the envisaged EU-USA PNR Agreement was duly challenged by the EP in Advisory Opinion 1/04, but this procedure was removed from the register when the Council went ahead with the conclusion of the Agreement without awaiting the Court's advisory opinion, see OJ C69/12 from 19 March 2005. The EP then successfully imitated annulment proceedings against the EU-USA PNR Agreement, see Joined Cases C-317/04 and C-318/04 EU v Council (EUUSA PNR Agreement) ECLI:EU:C:2006:346. In order to avoid an open conflict between the EU and international legal orders, not to say a heads-on political clash with the USA, the CJEU stayed the effects of its judgment in the following terms at para 83: 'Given, first, the fact that the Community cannot rely on its own law as justification for not fulfilling the Agreement which remains applicable during the period of 90 days from termination thereof and, second, the close link that exists between the 
aftermath of the New York twin tower terrorist attack, geo-political and international security considerations thus seemed to prevail over the strict adherence to EU law obligations. In a post-Lisbon setting entailing the abolishment of the pillar structure, such matters have now firmly been brought within the EU balloon, as is illustrated by the negative opinion of the CJEU in relation to the EU-Canada PNR Agreement. ${ }^{75}$ In order to avoid a potential open clash between EU and international law obligations, the EU would be well advised to review and, where need be, also renegotiate the other existing PNR agreements in the light of this Advisory Opinion. ${ }^{76}$

In highly exceptional cases, the EU may not of itself be in a position to remedy the incompatibility between EU and international law but will instead need to rely on the goodwill of the international community to take action at an international level. A perfect example of the latter is offered by the Kadi saga concerning financial sanctions imposed on individuals in the fight against international terrorism. ${ }^{77} \mathrm{~A}$ potential conflict was clearly exposed between the respect for fundamental rights in the autonomous EU legal order and the UN respectively, which could only meaningfully be remedied at the UN level since the EU sanctions list was merely a copy and paste of the UN sanctions list. In its first Kadi appeal judgment, the CJEU maintained the effects of the contested sanctions regulation with regard to Mr Kadi for a maximum of three months so as to allow the Council to fix the shortcomings. ${ }^{78} \mathrm{~A}$ remedy was found at the UN level, in the form of the introduction of a summary narrative and creation of the position of an ombudsperson, ${ }^{79}$ but this was not in itself

Agreement and the decision on adequacy, it appears justified, for reasons of legal certainty and in order to protect the persons concerned, to preserve the effect of the decision on adequacy during that same period. In addition, account should be taken of the period needed for the adoption of the measures necessary to comply with this judgment.' This agreement was replaced by an EU-USA PNR Agreement based exclusively on the third pillar - Justice and Home Affairs - thus at the time bringing it outside the democratic control of the EP and the judicial control of the CJEU, see EU-US Agreement on the processing and transfer of passenger name record (PNR) data by air carriers to the United States Department of Homeland Security, 18 July 2007 [2007] OJ L204/18, 4 August 2007. On these procedural issues, see S Adam, 'Quelques réflexions sur les relations entre les procédures a priori et a posteriori d'examen de compatibilité des accords communautaires suite à l'affaire dite de l'accord PNR' (2006) Cahiers de Droit Européen 657-96.

75 Since the abolishment of the pillar structure by the Lisbon Treaty, both democratic and judicial control with respect to the area of freedom, security and justice have been firmly put at EU level in the hands of the EP and the CJEU and are thus now included in the balloon of the EU autonomous legal order. Interestingly, in Advisory Opinion 1/15 (PNR Agreement EU-Canada) ECLI:EU:C:2016:656 of 26 July 2017, also brought by the EP, the CJEU held that the envisaged PNR Agreement with Canada was incompatible with EU law both because of wrong legal basis and because of breach of fundamental rights in the following terms:

'1. The Council Decision on the conclusion, on behalf of the Union, of the Agreement between Canada and the European Union on the transfer and processing of Passenger Name Record data must be based jointly on Article 16(2) TFEU and Article 87(2)(a) TFEU.

2. The Agreement between Canada and the European Union on the transfer and processing of Passenger Name Record data is incompatible with Articles 7, 8 and 21 and Article 52(1) of the Charter of Fundamental Rights of the European Union in so far as it does not preclude the transfer of sensitive data from the European Union to Canada and the use and retention of that data.'

76 It remains to be seen whether third countries would respond favourably towards such a request for renegotiation. The Commission had posted its intention to do so before Advisory Opinion 1/15 was issued, but concrete steps since then have not been reported on the website, see https://ec.europa.eu/home-affairs/what-we-do/policies/police-cooperation/information-exchange/pnr_en (last accessed 12 September 2018).

77 For a more detailed analysis of the Kadi saga in terms of interacting legal orders, see also I Govaere, 'The Importance of International Developments in the Case-law of the European Court of Justice: Kadi and the Autonomy of the EC Legal Order' in M Hiscock and W van Caenegem (eds), The Internationalisation of Law: Legislation, Decision-Making, Practice and Education (Edward Elgar Publishing, 2010) 316-40.

${ }_{78}$ Kadi I (n 33) at para 375-76.

${ }^{79}$ For an assessment of this remedy, see J Kokott and C Sobotta, 'The Kadi Case - Constitutional Core Values and International Law - Finding the Balance?' (2012) European Journal of International Law 1015-1024. 
considered to be sufficient by the CJEU in the second Kadi appeal judgment. ${ }^{80}$ In the end a situation of lasting and open conflict between the requirements under the EU and UN legal orders was diverted when the UN Security Council deleted the name of Mr Kadi from the UN sanctions list. ${ }^{81}$ However, this was very much an ad hoc solution which prevented a pointed puncturing of the EU balloon, but it does not offer a satisfactory and structural answer in the long term.

\section{Setting Aside EU Obligations in Favour of International Obligations of Member States}

Another possibility for the Member States only, is to squarely set aside EU obligations including under primary EU law in order to meet conflicting international obligations. The EU Treaties have always expressly allowed for such a solution in two sets of provisions, Article 351 TFEU concerning prior agreements of the Member States and the so-called security exceptions in Articles 346-348 TFEU. Hence it was acknowledged from the start that the EU and international law obligations of the Member States may not always fully coincide. It is clear, however, that such a solution is mainly intended to avoid the Member States incurring international liability and may not be invoked by the EU itself. The EU and its institutions are unconditionally bond by the EU Treaties by which they were set up. In fact those provisions, read together with the Advisory Opinion procedure of Article 218 (11) TFEU, and, since the Lisbon Treaty, also the clear objective stated in Article 3(5) TEU, may support the point of view that according to the Treaties, the EU is meant to always act in compliance with international law obligations; at least the EU Treaties do not foresee a situation where it would not.

The first possibility laid down in Article 351 TFEU ${ }^{82}$ allows Member States to invoke conflicting prior Treaty obligations so as to temporarily set aside the EU Treaties, in line with the international law principles on successive treaties. ${ }^{83}$ As such the underlying idea is that the Member States should not incur international liability for setting up or having joined the EU legal order with potentially conflicting obligations. In the Burgoa case the CJEU stressed that

the purpose of that provision is to lay down, in accordance with the principles of international law, that the application of the Treaty does not affect the duty of the

80 Kadi II (n 33) at para 163.

81 See, among others, European Parliamentary Research Service, Briefing October 2016, 'Counterterrorist Sanctions Regimes Legal Framework and Challenges at UN and EU Levels' at 11, www.europarl.europa.eu/RegData/etudes/BRIE/2016/589864/EPRS_BRI\%282016\%29589864_EN.pdf (last accessed 12 September 2018).

82 Art 351 TFEU:

'The rights and obligations arising from agreements concluded before 1 January 1958 or, for acceding States, before the date of their accession, between one or more Member States on the one hand, and one or more third countries on the other, shall not be affected by the provisions of the Treaties.

To the extent that such agreements are not compatible with the Treaties, the Member State or States concerned shall take all appropriate steps to eliminate the incompatibilities established. Member States shall, where necessary, assist each other to this end and shall, where appropriate, adopt a common attitude.

In applying the agreements referred to in the first paragraph, Member States shall take into account the fact that the advantages accorded under the Treaties by each Member State form an integral part of the establishment of the Union and are thereby inseparably linked with the creation of common institutions, the conferring of powers upon them and the granting of the same advantages by all the other Member States'.

83 See, eg, A Rosas, 'The Status in EU Law of International Agreements Concluded by EU Member States' (2011) 34 Fordham International Law Journal 5, 1304-45. 
Member State concerned to respect the rights of non-member countries under a prior agreement and to perform its obligations thereunder. ${ }^{84}$

Under international law the Member States and the EU each have a distinct legal personality thus potentially triggering also distinct international liability. In a post-Lisbon setting which in Article 47 TEU expressly acknowledges that the EU shall have legal personality, the CJEU however seems inclined to blur those distinct legal personalities into one for the sake of application of EU law. As such, contrary to Advocate General Sharpston, the CJEU stated in Opinion 2/15 on the EUSFTA, that prior Member States' agreements were simply considered to be 'replaced' by later EU agreements so that neither the application of Article 351 TFEU nor a mixed agreement in order to terminate those prior Treaty obligations was warranted. ${ }^{85}$ It is questionable that such a reasoning is consonant with international law. Furthermore, by virtue of Article 351(2) TFEU, the obligation rests on the Member States to 'extinguish' any such incompatibility, which implies to proceed to solve the conflict in favour of compliance with EU law. ${ }^{86}$ The CJEU seems to interpret this as an obligation as to result rather than an obligation as to means. ${ }^{87}$ Again, such an approach may put the Member States in a difficult position vis a vis the third countries involved, in particular if the latter are unwilling to cooperate, and raise issues concerning their international liability. It may thus be questioned whether the CJEU has not at least in part forsaken the very raison d'être of this provision to the detriment of the Member States as international actors.

A second set of rules concern the so-called security exceptions of Articles 346-348 TFEU. ${ }^{88}$ These are basically safety valves that may be triggered by Member

${ }^{84}$ Case 812/79 Burgoa ECLI:EU:C:1980:231 at para 8. This is in line with Art 30 of the Vienna Convention on the Law of Treaties, although it should be noted that under EU law Member States may only invoke prior 'rights of third countries' and hence prior 'obligations of the Member states' vis-à-vis those third countries in order to set aside the EU Treaties, which is more limited than under international law.

85 Opinion 2/15 EUSFTA ECLI:EU:C:2017:376 at para 254-55.

${ }^{86}$ See Art 351(2) TFEU.

87 See inter alia Case C- 205/06 Commission v Austria ECLI:EU:C:2009:118; Case C-84/98 Commission v Portugal ECLI:EU:C:2000:359. In the latter case, the CJEU concluded that 'by failing to denounce or adjust the agreement on merchant shipping with the Federal Republic of Yugoslavia (...)the Portuguese Republic failed to fulfil its obligations under Articles 3 and 4(1) of that regulation'. For an analysis, see J Klabbers, 'Moribund on the Fourth of July? The Court of Justice on Prior Agreements of the Member States' (2001) European Law Review 187-97.

${ }^{88}$ Art 346 TFEU:

'1. The provisions of the Treaties shall not preclude the application of the following rules:

(a) no Member State shall be obliged to supply information the disclosure of which it considers contrary to the essential interests of its security;

(b) any Member State may take such measures as it considers necessary for the protection of the essential interests of its security which are connected with the production of or trade in arms, munitions and war material; such measures shall not adversely affect the conditions of competition in the internal market regarding products which are not intended for specifically military purposes.

2. The Council may, acting unanimously on a proposal from the Commission, make changes to the list, which it drew up on 15 April 1958, of the products to which the provisions of paragraph 1(b) apply'.

Art 347 TFEU:

'Member States shall consult each other with a view to taking together the steps needed to prevent the functioning of the internal market being affected by measures which a Member State may be called upon to take in the event of serious internal disturbances affecting the maintenance of law and order, in the event of war, serious international tension constituting a threat of war, or in order to carry out obligations it has accepted for the purpose of maintaining peace and international security'.

Art 348 TFEU:

'If measures taken in the circumstances referred to in Art 346 and 347 have the effect of distorting the conditions of competition in the internal market, the Commission shall, together with the State concerned, examine how these measures can be adjusted to the rules laid down in the Treaties.

By way of derogation from the procedure laid down in Art 258 and 259, the Commission or any Member State may bring the matter directly before the Court of Justice if it considers that another Member State is making improper use of the powers provided for in Art 346 and 347. The Court of Justice shall give its ruling in camera'. 
States in case they feel that their essential security interests are at stake. ${ }^{89}$ The Treaty expressly mentions the possibility for Member States to set aside the EU Treaties inter alia with respect to the divulgence of security related information, ${ }^{90}$ or 'to carry out obligations it has accepted for the purpose of maintaining peace and international security'. The latter indirect reference to UN Security Council resolutions which are binding on the Member States can of course not go unnoticed and offers a solution to potentially conflicting obligations which is firmly in favour of international law. An important fact thereby is that under the security exceptions, contrary to Article 351 TFEU, the EU Treaty obligations may be set aside without an indication of duration nor the requirement to ultimately solve the conflict in favour of compliance with EU law. Not surprisingly therefore, the CJEU has ruled that the security exceptions present a 'wholly exceptional situation' ${ }^{91}$ and do not give a free hand for the Member States to derogate from EU obligations at will. Member States have to show that such derogation is necessary in order to protect its essential security interests'.$^{92}$ Under Article 348 TFEU the CJEU will exercise a marginal judicial review mainly to ensure that the security exceptions are not 'misused' by the Member States or abusively triggered. ${ }^{93}$

Both sets of rules leave the appreciation and autonomy of the EU legal order intact, whilst simultaneously allowing for Member States' compliance with conflicting international law obligations. This may in practice solve an apparent clash with Member States' mandatory compliance with UN obligations under Article 103 of the UN Charter. The CJEU has in the past expressly accepted such a solution subject to a strict necessity test, for instance in the Centro-Com case where the UK sought to reinforce a UN security council resolution in breach of the EU principle of mutual trust between Member States. ${ }^{94}$ It would of course be unacceptable within the EU balloon to accommodate the UK measure by giving in on such a fundamental principle as the mutual trust between the Member States. The ultimate and perhaps more unexpected EU law solution was therefore to allow for the EU legal order balloon to be pushed aside by well identified international obligations of the Member State concerned, rather than incorporating conflicting elements of international law into the EU balloon. Also, this is a necessary form of resilience in order to keep the EU law balloon afloat.

\section{Post-Lisbon: Will the Balloon Fly or Deflate?}

This exercise of maintaining a sufficient degree of resilience naturally becomes all the more important, but also increasingly difficult, as the EU law balloon is inflated to its near full capacity. As a consequence, the structural pressure exponentially increases whereas the balloon membrane itself becomes more fragile and vulnerable to puncturing. The crucial question to determine the viability of the autonomous EU legal order in the long run is therefore whether the balancing trick performed by the CJEU between a hermetically closed system, but with sufficient resilience to avoid conflicts with international law, is still adequate and/or sufficient in a post-Lisbon setting.

\footnotetext{
${ }^{89}$ See, eg, M Trybus, 'The EC Treaty as an Instrument of European Defence Integration: Judicial Scrutiny of Defence and Security Exceptions' (2002) Common Market Law Review 1347-72.

90 Which was an issue in the Kadi saga above.

${ }^{91}$ Case 222/84 Johnston ECLI:EU:C:1986:206 at para 27.

92 See, eg, Case C- 187/16 Commission v Austria ECLI:EU:C:2018:194 at para 78.

${ }^{93}$ For an interesting analysis of the nature of judicial review relating to the security exceptions, see the opinion of Advocate General Jacobs in the FYROM Case C-120/94 Commission v Greece ECLI:EU:C:1995:109, esp at para 61-72.

${ }^{94}$ Case C-124/95 Centro-Com ECLI:EU:C:1997:8.
} 
The challenges which the CJEU and the EU legal order at large face in this respect are not to be underestimated. Opinion 2/13 especially has triggered much criticism, calling upon the CJEU to be more open to interaction with international law. Such a reaction seems to be somewhat misguided though, as the insertion by the Lisbon Treaty of the express reference to accession of the EU to the ECHR has not raised for the first time, but only fundamentally altered, the nature of the possible interaction between those two legal orders. Prior to the Lisbon Treaty this interaction was found, as mentioned above, in accommodating and even openly integrating ECHR elements into the formulation of EU law, so as to render both legal systems compatible as well as complementary. The post-Lisbon quest to find the proper modalities for accession of the EU to the ECHR for the first time raises new and important issues specifically relating to the structural autonomy of the EU legal order in relation to the ECHR. Little or no guidance is currently offered in Opinion 2/13, nor in legal doctrine, on how the EU may accede to the ECHR without losing out on the specificities of the autonomous EU legal system and potentially thus puncturing the balloon.

The occurrence of such fundamentally conceptual legal problems is not, however, limited to the relationship between the EU and the ECHR legal systems. The structural pressure necessarily shifts and triggers concerns for the autonomy of the EU legal order whenever legal issues that before were kept outside the EU balloon are gradually integrated into EU law. As such, for instance also the extension of the scope of the CCP by the Lisbon Treaty to include foreign investments now raises fundamental issues relating to the compatibility, or not, of the ISDS provisions in important trade agreements such as CETA and EUSFTA with the autonomy of the EU legal order. The recent Achmea ${ }^{95}$ case further fuels this debate in relation to Member States BITs.

Besides those newly emerging structural issues inherent to the dynamic process of inflating the EU balloon, due attention should also continue to be given to increasing the resilience of the EU legal order so as to avoid open clashes with international law. Also in this respect some troublesome remnants of inconclusively or unsatisfactorily resolved issues remain on the table in a post-Lisbon setting. Among those it may suffice to raise the following questions which are likely to emerge in the future. How to avoid a clash with international obligations of the EU in case the CJEU finds that the conclusion of an EU agreement is incompatible with EU law, but where no easy EU law solution is possible due to lack of consensus on the expediency or content of the agreement? It will be interesting to follow up on the above mentioned PNR Agreements saga in this respect in a renewed post-Lisbon setting, whereby the pillar structure was abolished and the content of the EU balloon enlarged to include the area of freedom, security and justice. Similarly, what would be the impact in case the removal of an incompatibility by international means is not deemed sufficient to align to EU law obligations? It may suffice here to recall the Kadi saga which was ultimately solved but only through an 'ad hoc' international remedy, namely the pointed removal of the name of Kadi from the UN sanctions list.

Ideally, the procedural remedies in the Treaties to avoid a clash between EU and international law, the so-called 'bridges' between EU and international law, would prevent the occurrence of difficult practical legal issues related to conflicts between legal systems. In order for the balloon to continue flying, it might be beneficial for the CJEU to revisit and further explain those mechanisms. Article 351 TFEU essentially seeks to shield Member States from incurring international liability for joining the EU, whereas the primary aim of the advisory opinion procedure of Article 218(11) TFEU is to prevent the EU from incurring international liability for contracting international law obligations which are contrary to EU law.

\footnotetext{
${ }^{95}$ Achmea (n 31).
} 
As mentioned above, a matter of concern for the Member States is that the EU law obligation to 'extinguish' the incompatibility of prior agreements in favour of EU law pursuant to Article 351(2) TFEU may in practice prove difficult to align to their international law obligations. More radical even was the position taken by the CJEU, in Opinion 2/15 on the EUSFTA, that prior Member States' agreements are simply replaced by later EU agreements so that neither the application of Article 351 TFEU nor a mixed agreement in order to terminate those prior Treaty obligations was warranted. There seems to be a sense of urgency in forging a renewed reflection on how to smoothly interconnect legal orders whilst avoiding Member States potentially incurring international liability for complying with EU law obligations.

Similarly, the CJEU has consistently held that the Advisory Opinion procedure of Article 218(11) TFEU serves to 'forestall' complications that might arise if an EU agreement were later on found to be incompatible with EU law. The crucial condition thereto is of course that this advisory opinion procedure is duly triggered in case of doubt. The Treaty thus contains merely a mechanism but no guarantee that such liability can at all times be avoided. A second issue concerns the expected outcome in case a negative opinion is formulated by the CJEU. The CJEU seems to have understood in the aftermath of Opinion 2/13 on the accession of the EU to the ECHR that merely concluding to an incompatibility between legal orders is not necessarily perceived as the most constructive and forward looking solution. In the later Opinion $1 / 15$ on the EU-Canada PNR Agreement, it proceeded to indicate more concrete and substantive solutions for the removal of the established incompatibility in terms of fundamental rights protection. ${ }^{96}$ Yet other than merely pinpointing and forestalling

96 Opinion 1/15 (n 75). The CJEU held: 'The Agreement between Canada and the European Union on the transfer and processing of Passenger Name Record data must, in order to be compatible with Art 7 and 8 and Art 52(1) of the Charter of Fundamental Rights:

(a) determine in a clear and precise manner the PNR data to be transferred from the European Union to Canada;

(b) provide that the models and criteria used in the context of automated processing of PNR data will be specific and reliable and non-discriminatory; provide that the databases used will be limited to those used by Canada in relation to the fight against terrorism and serious transnational crime;

(c) save in the context of verifications in relation to the pre-established models and criteria on which automated processing of Passenger Name Record data is based, make the use of that data by the Canadian Competent Authority during the air passengers' stay in Canada and after their departure from that country, and any disclosure of that data to other authorities, subject to substantive and procedural conditions based on objective criteria; make that use and that disclosure, except in cases of validly established urgency, subject to a prior review carried out either by a court or by an independent administrative body, the decision of that court or body authorising the use being made following a reasoned request by those authorities, inter alia, within the framework of procedures for the prevention, detection or prosecution of crime;

(d) limit the retention of Passenger Name Record data after the air passengers' departure to that of passengers in respect of whom there is objective evidence from which it may be inferred that they may present a risk in terms of the fight against terrorism and serious transnational crime;

(e) make the disclosure of Passenger Name Record data by the Canadian Competent Authority to the government authorities of a third country subject to the condition that there be either an agreement between the European Union and that third country equivalent to the Agreement between Canada and the European Union on the transfer and processing of Passenger Name Record data, or a decision of the European Commission, under Art 25(6) of Directive 95/46/EC of the European Parliament and of the Council of 24 October 1995 on the protection of individuals with regard to the processing of personal data and on the free movement of such data, covering the authorities to which it is intended that Passenger Name Record data be disclosed;

(f) provide for a right to individual notification for air passengers in the event of use of Passenger Name Record data concerning them during their stay in Canada and after their departure from that country, and in the event of disclosure of that data by the Canadian Competent Authority to other authorities or to individuals; and

(g) guarantee that the oversight of the rules laid down in the Agreement between Canada and the European Union on the transfer and processing of Passenger Name Record data relating to the protection of air passengers with regard to the processing of Passenger Name Record data concerning them will be carried out by an independent supervisory authority'. 
potential conflicts, could this procedure not also be used as an important vehicle for the CJEU to better clarify the dynamics of the EU balloon and its complex interactions with international law? Admittedly, such a proposal implies more proactively using the advisory opinion procedure for an additional and explicative function. But it is one which is currently lacking and for which there appears to be much need and demand.

In a post-Lisbon setting, more than before attention has gone to the concept of the autonomous EU legal order and how it impacts on the objective to establish the EU as forceful international actor. ${ }^{97}$ In the worst case scenario this concept would always be looming and unexpectedly pop up, as some kind of Loch Ness monster, in order to upset smooth international relations involving the EU and its Member States. Through the use of a balloon dynamics analysis, the above analysis to a large extent dispels such a perception. Instead it illustrates that the CJEU's approach to interconnecting the EU legal order with international law is much more structured and comprehensive, albeit highly complex and in urgent need of enhanced transparency.

97 See, eg, C Contartese, 'The Autonomy of the EU Legal Order in the ECJ's External Relations Case Law: From the "Essential" to the "Specific Characteristics" of the Union and Back Again' (2017) Common Market Law Review 1627-71; J Czuzai, 'The Autonomy of the EU Legal Order and the Lawmaking Activities of International Organizations: Some Examples Regarding the Council's most Recent Practice' (2012) 31 Yearbook of European Law 1, 452-72; S Hindelang, 'The Autonomy of the European Legal Order' in M Bungenberg and C Herrmann (eds), Common Commercial Policy after Lisbon. European Yearbook of International Economic Law (Springer, 2013) 187-98; JW van Rossem, 'The Autonomy of EU Law: More is Less?' in RA Wessel and S Blockmans (eds), Between Autonomy and Dependence (TMC Asser Press, 2013) 13-46; TS Lock, 'Walking on a Tightrope: The Draft ECHR Accession Agreement and the Autonomy of the EU Legal Order' (2011) Common Market Law Review 1025-54. 


\section{RESEARCH PAPERS IN LAW}

1/2003, Dominik Hanf et Tristan Baumé, "Vers une clarification de la répartition des compétences entre l'Union et ses Etats Membres? Une analyse du projet d'articles du Présidium de la Convention".

2/2003, Dominik Hanf, "Der Prozess der europäischen Integration in Belgien. Voraussetzung und Rahmen der Föderalisiserung eines ehemaligen Einheitsstaats".

3/2003, Dominik Hanf, "Talking with the "pouvoir constituant" in times of constitutional reform: The European Court of Justice on Private Applicants' Access to Justice".

4/2003, Horst Dippel, "Conventions in Comparative Constitutional Law".

5/2003, Ludwig Krämer, "Access to Environmental Information in an Open European Society - Directive 2003/4".

6/2003, Ludwig Krämer, “Uberlegungen zu Ressourceneffizienz und Recycling”.

7/2003, Ludwig Krämer, "The Genesis of EC Environmental Principles”.

8/2003, Takis Tridimas, "The European Court of Justice and the Draft Constitution: A Supreme Court for the Union?".

1/2004, Dominik Hanf et Pablo Dengler, "Accords d'association".

2/2004, David Mamane, "Reform der EU-Wettbewerbsregeln für TechnologietransferVerträge: Einfahrt in den sicheren Hafen?".

3/2004, Donald Slater and Denis Waelbroeck, "Meeting Competition : Why it is not an Abuse under Article 82".

4/2004, Jacques Bourgeois and Tristan Baumé, "Decentralisation of EC Competition Law Enforcement and General Principles of Community Law". 
5/2004, Rostane Mehdi, "Brèves observations sur la consécration constitutionnelle d'un droit de retrait volontaire".

1/2005, Jacques Pelkmans, "Subsidiarity between Law and Economics".

2/2005, Koen Lenaerts, "The Future Organisation of the European Courts".

3/2005, John A.E. Vervaele, "The Europeanisation of Criminal Law and the Criminal Law Dimension of European Integration".

4/2005, Christine Reh and Bruno Scholl, "The Convention on the Future of Europe: Extended Working Group or Constitutional Assembly?"

5/2005, John A.E. Vervaele, "European Criminal Law and General Principles of Union Law".

6/2005, Dieter Mahncke, "From Structure to Substance: Has the Constitutional Treaty improved the Chances for a Common Foreign and Security Policy?".

1/2006, Dominik Hanf, "Le développement de la citoyenneté de l'Union européenne".

2/2006, Vassilis Hatzopoulos, Thien Uyen Do, "The Case Law of the ECJ concerning the Free Provision of Services : 2000 - 2005".

3/2006, Dominik Hanf, "Réformes institutionnelles sans révision du traité?", (document de discussion).

4/2006, Elise Muir, "Enhancing the effects of EC law on national labour markets, the Mangold case".

5/2006, Vassilis Hatzopoulos, "Why the Open Method of Coordination (OMC) is bad for you: a letter to the EU".

6/2006, Vassilis Hatzopoulos, "The EU essential facilities doctrine".

7/2006, Pablo Ibáñez Colomo, "Saving the Monopsony: Exclusivity, Innovation and Market Power in the Media Sector".

1/2007, Pablo Ibáñez Colomo, "The Italian Merck Case”.

2/2007, Imelda Maher, "Exploitative Abuses: Which Competition Policy, Which Public Policy?".

3/2007, Vassilis Hatzopoulos, "With or without you... judging politically in the field of Area of Freedom, Security and Justice?".

4/2007, Matteo Pierangelo Negrinotti, "The AstraZeneca Case".

5/2007, Vassilis Hatzopoulos, "Que reste-t-il de la directive sur les services?".

6/2007, Vassilis Hatzopoulos, "Legal Aspects in Establishing the Internal Market for services".

7/2007, Vassilis Hatzopoulos, "Current Problems of Social Europe". 
1/2008, Vassilis Hatzopoulos, "Public Procurement and State Aid in National Healthcare Systems".

2/2008, Vassilis Hatzopoulos, "Casual but Smart: The Court's new clothes in the Area of Freedom Security and Justice (AFSJ) after the Lisbon Treaty".

3/2008, Takis Tridimas and José A. Gutiérrez-Fons, "EU Law, International Law and Economic Sanctions against Terrorism: The Judiciary in Distress?".

4/2008, Ludwig Krämer, "Environmental judgments by the Court of Justice and their duration".

5/2008, Donald Slater, Sébastien Thomas and Denis Waelbroeck, "Competition law proceedings before the European Commission and the right to a fair trial: no need for reform?".

$1 / 2009$, Inge Govaere, "The importance of International Developments in the caselaw of the European Court of Justice: Kadi and the autonomy of the EC legal order".

2/2009, Vassilis Hatzopoulos, "Le principe de reconnaissance muTEUlle dans la libre prestation de services".

3/2009, Dominik Hanf, "L'encadrement constitutionnel de l'appartenance de l'Allemagne à l'Union européenne. L'apport de l'arrêt «Lisbonne » de la Cour constitutionnelle fédérale".

1/2010, Vassilis Hatzopoulos, "Liberalising trade in services: creating new migration opportunities?"

2/2010, Vassilis Hatzopoulos \& Hélène Stergiou, "Public Procurement Law and Health care: From Theory to Practice"

3/2010, Dominik Hanf, "Vers une précision de la Europarechtsfreundlichkeit de la Loi fondamentale - L'apport de l'arrêt « rétention des données » et de la décision « Honeywell » du BVerfG"

1/2011, Nicoleta Tuominen, "Patenting Strategies of the EU Pharmaceutical Industry - Crossroad between Patent Law and Competition Policy"

2/2011, Dominik Hanf, "The ENP in the light of the new "neighbourhood clause" (Article 8 TEU)"

3/2011, Slawomir Bryska, "In-house lawyers of NRAs may not represent their clients before the European Court of Justice - A case note on UKE (2011)"

4/2011, Ann Fromont et Christophe Verdure, "La consécration du critère de l'« accès au marché » au sein de la libre circulation des marchandises : mythe ou réalité ?"

5/2011, Luca Schicho, "Legal privilege for in-house lawyers in the light of AKZO: a matter of law or policy?" 
6/2011, Vassilis Hatzopoulos, "The concept of 'economic activity' in the EU Treaty: From ideological dead-ends to workable judicial concepts"

1/2012, Koen Lenaerts, "The European Court of Justice and Process-oriented Review"

2/2012, Luca Schicho, "Member State BITs after the Treaty of Lisbon: Solid Foundation or First Victims of EU Investment Policy?"

3/2012, Jeno Czuczai, "The autonomy of the EU legal order and the law-making activities of international organizations. Some examples regarding the Council most recent practice"

4/2012, Ben Smulders and Katharina Eisele, "Reflections on the Institutional Balance, the Community Method and the Interplay between Jurisdictions after Lisbon"

5/2012, Christian Calliess, "The Future of the Eurozone and the Role of the German Constitutional Court"

1/2013, Vassilis Hatzopoulos, "La justification des atteintes aux libertés de circulation : cadre méthodologique et spécificités matérielles"

2/2013, George Arestis, "Fundamental rights in the EU: three years after Lisbon, the Luxembourg perspective"

3/2013, George Nicolaou, "The Strasbourg View on the Charter of Fundamental Rights"

4/2013, Jean Sentenac, "L'autorisation inconditionnelle en phase II - De l'imperfection du règlement 139/2004"

5/2013, Vassilis Hatzopoulos, "Authorisations under EU internal market rules"

6/2013, Pablo González Pérez, "Le contrôle européen des concentrations et les leçons à tirer de la crise financière et économique"

7/2013, Michal Bobek \& David Kosař, "Global Solutions, Local Damages: A Critical Study in Judicial Councils in Central and Eastern Europe"

8/2013, Pablo González de Zárate Catón, "Disclosure of Leniency Materials: A Bridge between Public and Private Enforcement of Antitrust Law"

9/2013, Gianni Lo Schiavo, "The Judicial 'Bail Out' of the European Stability Mechanism: Comment on the Pringle Case. Case C-370/12, Thomas Pringle v. Government of Ireland, Ireland and The Attorney General, [2012] not yet reported"

1/2014, Ramses A. Wessel and Steven Blockmans, "The Legal Status and Influence of Decisions of International Organizations and other Bodies in the European Union"

2/2014, Michal Bobek, "The Court of Justice of the European Union" 
3/2014, Michal Bobek, "Judicial Selection, Lay Participation, and Judicial Culture in the Czech Republic: A Study in a Central European (Non)Transformation”

1/2015, Frédéric Allemand, "La Banque centrale européenne et la nouvelle gouvernance économique européenne : le défi de l'intégration différenciée“

1/2016, Inge Govaere, "TTIP and Dispute Settlement: Potential Consequences for the Autonomous EU Legal Order"

2/2016, Gareth Davies, "Migrant Union Citizens and Social Assistance: Trying to Be Reasonable About Self-Sufficiency"

3/2016, Miguel Ángel de Diego Martín, "Net Neutrality: Smart Cables or Dumb Pipes? An overview on the regulatory debate about how to govern the network"

4/2016, Inge Govaere, "To Give or to Grab: The Principle of Full, Crippled and Split Conferral of Powers Post-Lisbon"

1/2017, Vassilis Hatzopoulos, "From Economic Crisis to Identity Crisis: The Spoliation of EU and National Citizenships"

1/2018, Vincent Delhomme, "Between Market Integration and Public Health: The Paradoxical EU Competence to Regulate Tobacco Consumption"

2/2018, Inge Govaere, "Interconnecting Legal Systems and the Autonomous EU Legal Order: A Balloon Dynamic" 